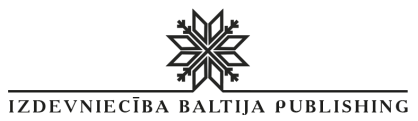

\title{
INTEGRATION OF TRADITIONAL \\ AND INNOVATIVE SCIENTIFIC RESEARCHES: GLOBAL TRENDS AND REGIONAL ASPECT
}

Collective monograph

Riga, Latvia 2020 
UDK 001(08)

$\operatorname{In} 720$

Title: Integration of traditional and innovative scientific researches: global trends and regional aspect

Subtitle: Collective monograph

Scientific editor and

project director: Anita Jankovska

Authors: Andriy Demyanchuk, Larysa Markevych, Svitlana Shchitova, Rostyslav Polishchuk, Mykola Sanakuiev, Iryna Klymchuk, Olena Shtraikher, Inna Melnyk, Oleksandr Moisak, Svitlana Fiialka, Lina Karlova, Olena Lesnovska, Roman Mylostyvyi, Mykola Kovalov, Valeriy Minukhin, Anatoliy Mel'nyk, Inna Torianyk, Tetiana Moiseienko, Gennadiy Khrystian, Inna Torianyk, Oleksiy Tkachenko, Olena Havrylina

Publisher: Publishing House "Baltija Publishing", Riga, Latvia

Available from: http://www.baltijapublishing.lv/omp/index.php/bp/catalog/book/74

Year of issue: 2020

All rights reserved. No part of this book may be reprinted or reproduced or utilized in any form or by any electronic, mechanical, or other means, now known or hereafter invented, including photocopying and recording, or in any information storage or retrieval system, without permission in writing from the publisher and author.

Integration of traditional and innovative scientific researches: global trends and regional aspect: collective monograph / edited by authors. - 3rd ed. - Riga, Latvia : "Baltija Publishing", 2020 - 268 p.

ISBN: 978-9934-26-001-8

DOI: https://doi.org/10.30525/978-9934-26-001-8-1

The collective monograph describes the integration of traditional and innovative scientific researches: global trends and regional aspect. The general issues of the fine arts, social philosophy, political science, social psychology, social communications, agricultural sciences, preventive medicine and veterinary sanitation are discussed. The publication is intended for scholars, teachers, postgraduate students, and students, as well as a wide readership. 


\section{Contents}

\section{CHAPTER «HISTORY OF ART»}

Andriy Demyanchuk

AUTHOR'S TECHNOLOGY OF THE MAKING

A MODERN ICON BASED ON THE EUROPEAN

PAINTING TECHNIQUES.

Larysa Markevych

POSTMODERN TENDENCIES IN UKRAINIAN BALLET

IN SOVIET TIMES IN THE 60S-80S OF THE $20^{\text {th }}$ CENTURY.

\section{Svitlana Shchitova}

POLYPHONY IN ORIGINAL WORKS FOR BANDURA.

\section{CHAPTER «PHILOSOPHICAL SCIENCES»}

\section{Rostyslav Polishchuk}

THE DEVELOPMENT OF PHYSICAL EDUCATION

AND SPORTS IN PARALLEL WITH THE FORMS

OF AXIAL PRODUCTIVITY OF SOCIETY

\section{Mykola Sanakuiev}

INFORMATION AS MOBILIZING FACTOR

OF SOCIAL ACTIVITY OF PERSONALITY

\section{CHAPTER «POLITICAL SCIENCES»}

\section{Iryna Klymchuk, Olena Shtraikher}

THE PECULIARITIES OF IMPLEMENTATION

OF GENDER POLICY IN SECURITY

AND DEFENSE SPHERES ON THE EXAMPLE

OF UN AND NATO

\section{CHAPTER «PSYCHOLOGICAL SCIENCES»}

\section{Inna Melnyk, Oleksandr Moisak}

PROBLEMS OF INTEGRATION OF PSYCHOLOGICAL

AND PEDAGOGICAL KNOWLEDGE IN THE PROCESS

OF PREPARATION OF FUTURE TEACHERS. 


\section{CHAPTER «SOCIAL COMMUNICATIONS»}

\section{Svitlana Fiialka}

FORMATION OF BEHAVIORAL NORMS OF PROFESSIONAL

COMMUNICATION FOR THE SCIENTIFIC COMMUNITY.

\section{CHAPTER «AGRICULTURAL SCIENCES»}

Lina Karlova, Olena Lesnovska, Roman Mylostyvyi

INFLUENCE OF THE TYPE OF NERVOUS ACTIVITY

ON THE MILK PRODUCTION OF COWS

Mykola Kovalov

SUBSTANTIATION OF APPLICATION OF EM-PRODUCTS

IN CLOSED RESOURCE-SAVING AGROECO COMPLEXES

\section{CHAPTER «MEDICAL SCIENCES»}

Valeriy Minukhin, Anatoliy Mel'nyk, Inna Torianyk

INFLAMMATORY PARODONTIC DISEASES.

CLASSICAL TRADITIONS OF MEDICAMENTAL

THERAPY AND CONTEMPORANEITY.

Tetiana Moiseienko, Gennadiy Khrystian, Inna Torianyk

HOP-PLANT CARBONATE EXTRACT.

TOXICITY. ORGANIC CHANGES

\section{CHAPTER «VETERINARY SCIENCES»}

Oleksiy Tkachenko, Olena Havrylina

PECULIARITIES OF PATHOMORPHOLOGICAL

DIAGNOSIS OF THE MOST COMMON

RESPIRATORY INFECTIONS OF A PIG 


\title{
CHAPTER «PSYCHOLOGICAL SCIENCES»
}

\author{
PROBLEMS OF INTEGRATION OF PSYCHOLOGICAL AND \\ PEDAGOGICAL KNOWLEDGE IN THE PROCESS \\ OF PREPARATION OF FUTURE TEACHERS
}

\section{ПРОБЛЕМИ ІНТЕГРАЦЇ̈ ПСИХОЛОГІЧНИХ \\ І ПЕДАГОГІЧНИХ ЗНАНЬ У ПРОЦЕСІ ПІДГОТОВКИ МАЙБУТНІХ ПЕДАГОГІВ}

\author{
Inna Melnyk ${ }^{1}$ \\ Oleksandr Moisak ${ }^{2}$
}

DOI: https://doi.org/10.30525/978-9934-26-001-8-33

Abstract. The article is devoted to the problems of psychological and pedagogical preparation of future educators and primary school teachers for professional activity. The aim of the article is to highlight the results of the study of the peculiarities of future teachers' awareness of the need to acquire psychological competencies for further work with children and outline the basic principles of interdisciplinary and integrated approach to teaching psychological and pedagogical disciplines in universities. A brief theoretical overview of modern research on professional and personal growth of teachers is given. The results of an empirical study of the peculiarities of students' awareness of the need to acquire psychological competencies for further work with children of preschool and primary school age are highlighted. It was stated that a significant part of the surveyed students are generally aware of the need to apply psychological knowledge in the future profession, but such awareness is significantly "blurred" and unstructured. It has been found that the vast majority of students are not fully aware of the purpose for which psychological and pedagogical disciplines are combined

\footnotetext{
${ }^{1}$ Ph.D. in Psychology,

Assistant Professor of the Department of Pedagogy and Psychology,

Borys Grinchenko Kyiv University, Ukraine.

${ }^{2}$ Senior Lecturer of the Department of Pedagogy and Psychology,

Borys Grinchenko Kyiv University, Ukraine.

(C) Inna Melnyk, Oleksandr Moisak
} 
into a common integrated course, which may indicate a lack of work to implement integrated and interdisciplinary approaches. It is determined that psychological knowledge is practically used more by students to improve their own lives and personal self-development, rather than directly in working with children. In this regard, some practical aspects of the integration of psychological and pedagogical knowledge in the training of specialists in the field of preschool and school education, in particular, in the study of such an integrated course as "Anthropology". The purpose, tasks and structure of the course are described, strategies of combination of psychological and pedagogical knowledge in the process of its teaching are defined, which consist in clear understanding by teachers of disciplines of psychological and pedagogical cycle of necessity of interaction among themselves and orientation on practical side of their subject application. The view of such structuring and teaching of this course is described, when the study focuses on psychological concepts and categories, that is the complete system of psychological research and indicates the possibility and method of application of this research in the pedagogical process.

\section{1. Вступ}

Питання, пов'язані з ефективною підготовкою майбутніх педагогів до професійної діяльності повсякчас турбують науковців, викладачів, суспільних діячів, діяльність яких так чи інакше пов'язана з вищою школою. На сучасному етапі професійна підготовка у вищих навчальних закладах освіти не заперечує прогресивних ідей минулого, але вимагає переосмислення і творчого розвитку всіх цінних здобутків щодо проблеми підготовки вчительських кадрів [16, с. 80]. Наявні на сьогодні державні документи України про освіту спрямовують вищі навчальні заклади педагогічних профілів на перегляд змісту, форм та методів професійної підготовки майбутніх спеціалістів. Так, у Державній національній програмі «Освіта» (Україна XXI століття) вказано, що «вища освіта спрямована на забезпечення фундаментальної підготовки фахівців, на формування інтелектуального потенціалу нації та всебічний розвиток особистості як найвищої цінності суспільства» [6]. Кожен педагог має бути абсолютно компетентним у своїй справі, любити іï, розуміти тонкощі внутрішнього світу своїх вихованців. Особливо це стосується майбутніх вихователів та вчителів початкових 
шкіл, оскільки на них покладається особливий обов'язок: в їх руки батьки віддаватимуть найцінніше, що в них є, свою маленьку дитину, яку педагог має не тільки навчити чомусь, передати знання, а й «виліпити» справжню гармонійно розвинену особистість. За законами природи у дошкільному та молодшому шкільному віці відбувається особливо бурхливий стрімкий психічний і особистісний розвиток малюка, і тому кожен фахівець, що працює 3 ним, має бути не тільки професійним педагогом, а й блискучим психологом, що здатен помітити і попередити найтонші негативні зміни у розвитку кожної дитини. Хороший педагог - це той, хто, за словами Гі Лефрансуа «не дивується розгубленості дитини раннього віку та агресивності підлітка» [4, с. 40], тобто той, хто знає все про психологічні особливості особистості та поведінки своїх вихованців, а також вміє використати найбільш ефективні методи та прийоми для навчання і виховання дітей відповідно до цих особливостей. Для цього необхідно не тільки мати відповідні знання, а й усвідомлювати, для чого саме вони потрібні, де і як саме найбільш доцільно можна ці знання застосувати.

Однак, наші спостереження показують, що студенти сьогодні цікавляться психологічними науками здебільшого $з$ метою глибшого пізнання своєї особистості. Рідко коли вони задумуються про перенесення цих знань на свою майбутню професійну діяльність. Крім того, нерідко у студентів формується так звана «подвійність думки», коли вони свідомо розуміють необхідність психологічного погляду на різні педагогічні ситуації, врахування індивідуально-психологічних особливостей кожної дитини, але часто на практиці реалізують зовсім інший підхід. Ці факти були підтверджені у процесі наших спостережень і досліджень на окремих вибірках студентів спеціальності «Дошкільна освіта» [12]. А між тим, для того, щоб бути справжнім психологом, необхідно не тільки мати відповідні знання, а й усвідомлювати, для чого саме вони потрібні, де і як саме найбільш доцільно можна ці знання застосувати.

Цікавим є той факт, що у навчальних планах більшості педагогічних вузів на сьогодні діє принцип інтеграції окремих педагогічних та психологічних дисциплін у одну загальну й цілісну. Безумовно, на наш погляд, така тенденція є дуже позитивною і необхідною, оскільки дійсно покликана сформувати у майбутніх фахівців ефективні психо- 
лого-педагогічні компетенції. Однак, на практиці багато викладачів все одно стикаються 3 деякими практичними проблемами у зв'язку 3 цим, а студенти часто змушені механічно запам'ятовувати навчальний матеріал і іноді не в змозі поєднати весь матеріал педагогічних і психологічних дисциплін в єдине ціле і усвідомити окремі теми, розділи в їх взаємозв'язках. На нашу думку, означені аспекти проблеми $\epsilon$ наразі досить актуальними, що зумовлює необхідність глибшого дослідження даної ситуації і пошуку шляхів більш ефективної підготовки майбутніх вихователів у цьому напрямку. Тому нами було організовано дослідження, що мало на меті дослідити особливості усвідомлення майбутніми педагогами необхідності набуття психологічних компетенцій для подальшої роботи 3 дітьми та окреслити основні принципи міждисциплінарного та інтегрованого підходу до організації викладання психолого-педагогічних дисциплін у ВНЗ з урахуванням даних аспектів. Відповідно до поставленої мети були окреслені й основні завдання нашого дослідження, а саме: на основі аналізу теоретико-методологічної бази дослідження провести власне емпіричне вивчення особливостей усвідомлення майбутніми педагогами необхідності набуття психологічних компетенцій; охарактеризувати важливі практичні аспекти інтеграції психологічних і педагогічних знань для підготовки майбутніх педагогів у процесі викладання інтегрованих дисциплін психолого-педагогічного циклу.

\section{2. Короткий огляд проблем психолого-педагогічної підготовки фахівців у наукових працях}

У вітчизняній та зарубіжній науці проблемам професійної підготовки майбутніх педагогів присвячена досить велика кількість досліджень. Видатні класики педагогічної науки, такі як Я. Коменський, Я. Корчак, С. Русова, В. Сухомлинський, К. Ушинський, у свій час заклали концептуальні основи до розуміння особистості ідеального вчителя. I хоча прямо про підготовку педагогів вони рідко згадували, але ці проблеми імпліцитно червоною ниткою пронизують майже всі ïx твори. Слід наголосити також на тому, що незважаючи на те, що в даний час створюються нові сучасні концепції і системи підготовки педагогів, погляди відомих класиків залишаються надзвичайно важливими і необхідними. Так, Т. Піроженко відзначає: «Час «розкидання 
дорогоцінних камінців» психолого-педагогічної спадщини минув і настав період, коли конче необхідно схаменутись, озирнутись і 3 позиції сьогодення осмислити перлини мудрих заповідей вітчизняних педагогів, які віддали своє життя служінню найдорогоціннішому дару природи - Дитині» [15, с. 101].

Серед сучасних науковців, педагогів, психологів та суспільних діячів, що займаються проблемами підготовки фахівців на педагогічній ниві на основі компетентнісно-орієнтованого підходу, можна виділити праці Ш. Амонашвілі, І. Беха, В. Бондаря, Е. Вільчковського, Л. Занкова, І. Зязюна, В. Кременя, Н. Кузьміної, О. Савченко, В. Семиченко, Н. Селіверстової, О. Сухомлинської та багатьох інших. Не можемо не згадати і ті дослідження, що безпосередньо стосуються питань формування «Я-концепції» в юнацькому віці, а саме усвідомлення студентами себе як майбутніх професіоналів, активних суспільних діячів, визначення свого місця в житті, власного життєвого шляху. Це, передусім, погляди Г. Абрамової, К. Альбуханової-Славської, Г. Андреєвої, Г. Балла, Р. Бернса, О. Бодальова, М. Боришевського, У. Джемса, I. Кона, С. Максименка, А. Петровського та ін. Вчені наголошують на тісному взаємозв'язку особистісного і професійного зростання у юнацькому віці. Так, на думку А. Маркової, у процесі професійного зростання молодої людини, яке проходить ряд етапів (допрофесіоналізм, професіоналізм, суперпрофесіоналізм, післяпрофесіоналізм) відбувається тісне переплетення професійної й особистісної «Я - Концепції», формується індивідуальний стиль діяльності й поведінки. Далі відбувається вихід особистості за рамки професійної діяльності, здійснюється реалізація основних життєвих цілей і в цьому випадку можна говорити про те, що професійна діяльність людини є детермінантою її особистісного становлення [11].

Для нашого дослідження особливо важливими видаються дослідження видатних класиків та сучасних психологів та педагогів, таких як А. Богуш, Л. Виготського, Н. Гавриш, О. Запорожця, О. Кононко, Г. Костюка, В. Котирло, В. Кузьменко, С. Кулачківської, С. Ладивір, Н. Лисенко, Т. Піроженко, 3. Плохій, Т. Поніманської, О. Савченко та ін., оскільки вони здебільшого стосуються питань особистісного і професійного розвитку фахівців у сфері дошкільної та початкової освіти. У своїх працях вчені обгрунтовують необхідність особистісного роз- 
витку майбутніх педагогів, формування у них проективних, організаторських і конструктивних умінь, а також умінь педагогічної діагностики, моделювання та аналізу педагогічних ситуацій, що виникають у процесі життєдіяльності дітей у дитячому садку та школі. А для цього необхідною $є$ не тільки професійна педагогічна, а й психологічна підготовка майбутніх фахівців.

У працях Ю. Красильника підсумовано різні напрями дослідження проблеми формування психолого-педагогічної компетентності у психолого-педагогічній літературі, а саме визначені такі аспекти: професійна компетентність педагога (Л. Алексєєва, В. Баркасі, В. Введенський, О. Дубасенюк, Л. Хоружа та ін.); педагогічна компетентність (В. Адольф, Н. Кузьміна, М. Лук’янова, Т. Шамова та ін.); аутопсихологічна компетентність (О. Шиян); управлінська компетентність керівників освітніх закладів (О. Мармаза, І. Семикін, О. Тонконога та ін.). Охарактеризовано основні підходи до дослідження професійної компетентності педагога - процесуальний (Н. Кузьміна): дослідження якості підготовки педагога до навчально-виховного процесу (гностичний і конструктивний компоненти), його діяльності в процесі навчально-виховного процесу (комунікативний і організаторський компоненти), контрольно-діагностичної діяльності (рефлексивний компонент); особистісний (В. Шувалова, С. Рогов, Б. Ананьєв, О. Щербаков): оцінювання знань і вмінь педагога, мотиваційний компонент; процесуально-особистісний (комплексний) підхід (А. Маркова): дослідження педагогічних (процесуальних) умінь педагога, результатів його праці (навченість і вихованість суб'єктів навчання); результативний підхід: дослідження результативності навчально-виховного процесу (I. Лернер, М. Скаткін, В. Раєвський), ступеня засвоєння суб'єктами навчання змісту програм навчальних дисциплін, набуття ними досвіду репродуктивної і творчої діяльності в межах конкретної навчальної дисципліни, зміни емоційно-ціннісного ставлення суб'єктів навчання до навчального змісту і діяльності в певній галузі [10].

У рамках компетентнісного підходу до підготовки фахівців у галузі педагогічної освіти досить часто можна зустріти таке поняття, як психологічна компетентність, що розуміється як: особливий мотиваційний стан - готовність проявляти цілеспрямовану активність на основі отриманих психологічних знань [5]; здатність особистості ефективно 
застосовувати структуровану систему знань для побудови та налагодження процесу особистісної, соціальної й професійної взаємодії [18]; здатність індивіда взаємодіяти з людьми в системі міжособистісних відносин, що включає в себе вміння орієнтуватися в соціальних ситуаціях, визначати особистісні особливості й емоційний стан інших людей, обирати адекватні способи спілкування [7]; здатність особистості до самопізнання, самоконтролю, до ефективного спілкування і взаємодії з іншими людьми, саморозвитку та самореалізації, яка дозволяє людині розуміти себе та інших, ефективно адаптуватися до життя у сучасному соціумі, мати гармонійні стосунки з оточенням, успішно реалізовувати свій особистісний потенціал, відчувати високий рівень психологічного благополуччя та бути задоволеною життям [2]. Психологічну компетентність незмінно розглядають як обов'язкову складову професійної компетентності педагога. У цьому аспекті ії розуміють як: систему психічних властивостей, що визначають успішність виконання педагогічної діяльності [1]; психологічні знання і досвід, необхідні для ефективної педагогічної роботи [8]; інтегральну акмеологічну характеристику вчителя, що дозволяє конструктивно вирішувати завдання професійної діяльності, спілкування і саморозвитку [20]; сукупність навичок, які міжнародні експерти відносять до соціальної компетентності, а також окремі вміння, що включає в себе ініціативність та підприємливість [2].

Аналіз наукових джерел показав, що незважаючи на досить велику кількість наукових праць на тему формування психолого-педагогічної компетентності майбутніх педагогів, проблема поєднання педагогічних та психологічних знань при підготовці фахівців у процесі викладання інтегрованих психолого-педагогічних курсів глибоко не вивчалася, що зумовлює необхідність дослідження даної ситуації і пошуку шляхів більш ефективної підготовки майбутніх вихователів у цьому напрямку.

\section{3. Емпіричне вивчення особливостей усвідомлення майбутніми педагогами необхідності набуття психологічних компетенцій: методологія дослідження, результати та дискусії}

Аналіз теоретико-методологічної бази дослідження показав необхідність емпіричного вивчення особливостей усвідомлення майбутніми педагогами необхідності набуття психологічних компетенцій. 
Оскільки попередні наші попередні дослідження на малій вибірці студентів четвертого курсу КУ імені Бориса Грінченка напряму підготовки «Дошкільна освіта» [12] дозволили припустити про їх недостатню обізнаність у тому, навіщо необхідні психологічні знання майбутньому вихователю i де конкретно та в який спосіб можна їх застосувати, то було вирішено здійснити більш масштабне емпіричне дослідження даної проблеми. До вибірки увійшли студенти першого та другого курсів спеціальностей «Дошкільна освіта» (102 особи) та «Початкова освіта» (100 осіб) КУ імені Бориса Грінченка, оскільки саме ці студенти за навчальним планом вивчали психологічні дисципліни у складі інтегрованих курсів, таких як «Людинознавство» та «Психологія». Досліджуваним були запропоновані спеціальні опитувальники, які дозволили отримати інформацію про те, чи подобаються студентам психологічні науки взагалі, які психологічні дисципліни їм запам'яталися за період навчання та які з них вивчалися у складі цілісних інтегрованих курсів, з якою метою, на думку досліджуваних, вони введені в навчально-виховний процес саме у такому вигляді, як саме досліджувані використовують психологічні знання в житті, чи потрібні, на їхню думку, такі знання майбутньому педагогу та як саме можна їх використовувати у майбутній професійній діяльності.

Проаналізуємо результати даного опитування. Як показало наше дослідження, значна кількість респондентів висловили позитивне загальне ставлення до психологічних наук $(96,5 \%)$. I лише $3,5 \%$ опитаних відмітили, що психологія їх не цікавить зовсім. Майже всі студенти змогли повно перерахувати ті психологічні дисципліни, які вони вивчали за період навчання в інституті (94\%). Однак, цікаво, що дещо менша кількість студентів (а саме 76,2\%) змогли відзначити, що ці дисципліни викладалися у рамках інтегрованих курсів і назвати, яких саме. Так само важко студентам було відповісти на питання про те, з якою метою ці дисципліни були введені у навчальний процес саме у складі інтегрованих курсів. Близько половини з них відповіли на це запитання «не знаю» (47\%), а решта (53\%) надали короткі відповіді типу: «тому що психологія - це основа роботи педагога», «без психології не може бути й педагогіки», «ми маємо вивчати людину в цілісності» і таке інше. Ніхто із студентів не дав розгорнутої відповіді, де б могла прослідковуватися ïx думка щодо інтеграції кількох дисциплін в одну. Такі показники 
можуть свідчити про недостатність проведення роботи з впровадження інтегрованого та міждисциплінарного підходів і потребують посиленої уваги та злагодженої спільної роботи фахівців, що викладають ці курси.

49,5\% респондентів відзначили, що психологічні дисципліни введені в навчально-виховний процес для покращення їх власного життя (звучали такі відповіді, як-от: «для саморозвитку», «для самовдосконалення», «для розуміння себе», «для кращого розуміння людей», «для пізнання себе»). 43,1\% студентів, згадавши, що вони вчаться на майбутніх вихователів та вчителів, все ж таки відмітили, що психологія потрібна для роботи з дітьми, оскільки ці знання безпосередньо необхідні педагогу. І лише 7,4\% досліджуваних зазначили, що психологічні знання однаково необхідні і для особистісного, і для професійного зростання. Отже, можна узагальнити, що трохи більше половини студентів розуміють важливість психологічних знань для професії педагога і це вже $\epsilon$ хорошим показником.

Однак, контент-аналіз відповідей досліджуваних на наступне відкрите запитання «Чи використовуєте Ви психологічні знання у своєму житті? Як саме?» показав трохи інші результати. Тут вже 59,4\% студентів вказали, що в основному вони використовують набуті психологічні знання у спілкуванні з найближчим оточенням, в особистісних стосунках, при вирішенні конфліктних ситуацій, що виникають у повсякденному житті. А 40,6\% опитаних зазначили, що ці знання вони використовують або будуть використовувати перш за все на практиці під час роботи з дітьми.

Досить невтішні результати ми отримали при аналізі відповідей на запитання «У яких ситуаціях педагог може використовувати психологічні знання?». Тут припускалися розширені думки студентів, був наданий тривалий час для роздумів, однак повно відповісти на це запитання ніхто не зміг. Звичайно, досліджувані думали в правильному напрямку, але відповіді були обривисті, розпорошені. Так, найбільш розповсюдженими були такі думки, що по одній-дві зустрічалися у різних опитаних студентів: «при здійсненні індивідуального підходу», «під час супроводу дітей у періоди вікових криз», «при знаходженні спільної мови з батьками», «при діагностиці психічних станів дітей», «при організації дитячих ігор», «при розумінні тієї чи іншої негативної поведінки дитини». 
Отримані результати опитування закономірно наштовхують на пошук найбільш оптимальних форм та методів підготовки студентів 3 метою покращення даної ситуації. Деякі наковці серед основних вад традиційної системи підготовки майбутніх педагогів виділяють такі: 1) спрямованість тематики занять 3 дисциплін психолого-педагогічного циклу має в основному теоретичний характер і містить тільки окремі практичні питання; 2) у процесі вивчення психолого-педагогічних дисциплін знання теорії недостатньо трансформуються у метод моделювання, програмування і діагностики педагогічного процесу, пояснення сутності і суперечливості його явищ і об'єктів не стають основою для прийняття конкретних рішень у процесі практичної діяльності; 3) навчально-пізнавальна діяльність студентів здійснюється в основному на емпіричному рівні у форматі індуктивного шляху пізнання [20, с. 34].

Очевидно, що використання таких методів як лекції, семінари, практичні та лабораторні заняття у їх традиційному вигляді при вивченні окремих психологічних та педагогічних дисциплін на разі $\epsilon$ недостатнім. Ці методи $є$ ефективними перш за все для того, щоб студенти отримали ті чи інші психолого-педагогічні знання. Однак, для того, щоб майбутні вихователі дійсно усвідомили їх необхідність для майбутньої професії, знали, в яких конкретно ситуаціях їх можна практично застосувати, потрібно інтегрувати кілька дисциплін в одну i наповнювати традиційні заняття новими нетрадиційними елементами. Такі нетрадиційні елементи можна з успіхом використовувати при викладанні інтегрованих курсів, коли кілька викладачів разом можуть проводити спільні цікаві заняття. Найбільш широкі перспективи тут відкриваються саме при викладанні інтегрованих курсів, одним з яких $\epsilon$ «Людинознавство», враховуючи на його специфіку і здатність акумулювати в собі найбільш доцільну інтеграцію як педагогічних, так i психологічних аспектів організації роботи фахівця 3 дітьми.

\section{4. Інтеграція психологічних і педагогічних знань у процесі підготовки майбутніх педагогів}

Проблема інтеграції психологічних і педагогічних знань у процесі підготовки майбутніх педагогів є спільною як для студентів, так і для викладачів. Особливо це стосується викладачів інтегрованих дисциплін психолого-педагогічного циклу, для яких основним пріоритетом 
має бути, крім надання майбутнім педагогам глибоких психологічних та педагогічних знань, перш за все орієнтація на:

- ефективну взаємодію з усіма викладачами, що викладають інтегрований курс;

- взаємне обговорення з іншими викладачами тем, модулів інтегрованого курсу з метою уникання негативних моментів у навчальному процесі (протиріч, повторів і т.д.);

- практичний бік застосування тем кожного модуля у майбутній професійній діяльності студентів.

Дуже перспективним у плані інтеграції психологічних і педагогічних знань у процесі підготовки майбутніх педагогів $\epsilon$ інтегрований курс «Людинознавство», який вже третій рік поспіль викладається на першому курсі спеціальностей «Дошкільна освіта» та «Початкова освіта» першого (бакалаврського) рівня вищої освіти у Київському університеті імені Бориса Грінченка. Програма навчальної дисципліни «Людинознавство» включає в себе три модулі: «Анатомія, фізіологія людини з основами медичних знань», «Психологічна антропологія», «Педагогічна антропологія».

Для майбутнього фахівця у сфері педагогічної діяльності цілісне уявлення про біологічну, психологічну та соціальну сутність людини, про людину як учасника освітнього процесу є базовим, оскільки він повинен самостійно створювати та організовувати оптимальні умови для іiі повноцінного розвитку. Високої соціальної значущості вивчення курсу «Людинознавство» набуває для майбутніх вихователів ЗДО та вчителів початкових класів 3ЗСО, оскільки саме на ранніх етапах онтогенезу людини формуються фундаментальні основи для іiі розвитку у всій іiі багатогранності буття. Вивчення курсу «Людинознавство» дає унікальну можливість у систематичному вигляді зрозуміти будову, функції та рівні організації організму людини, природу людської психології, її специфіку, а також узагальнити ці знання для формування інтегрованого погляду на людину як учасника освітньо-виховного процесу. Зміст, структура, методи і форми психолого-педагогічної підготовки майбутнього фахівця у системі цього курсу максимально орієнтовані на педагогічну діяльність. Матеріал курсу «Людинознавство» побудований з дотриманням гуманітарної парадигми щодо пізнання людини. 


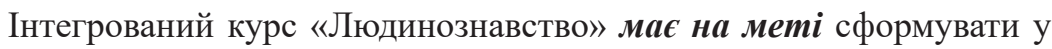
студентів педагогічних спеціальностей розуміння сутності людини як системи (біологічної, психологічної та соціальної) в філогенетичному та онтогенетичному розвитку з метою розвитку у них здатності ефективно вирішувати завдання щодо збереження і зміцнення здоров'я (фізичного, психічного, соціального та духовного) як власного, так і оточуючих. Основними його завданнями є: сформувати знання про будову, функції та рівні організації організму людини задля збереження iї фізичного здоров'я у навчально-виховному процесі; сформувати цілісний психологічний погляд на людину як носія образів суб'єктивної реальності (індивідного, суб'єктного, особистісного, індивідуального та універсального) з метою забезпечення психічного здоров'я всіх учасників освітнього процесу; сформувати знання про людину, як соціальну істоту здатну до розвитку та саморозвитку 3 метою вироблення власної позиції педагога щодо безпечної організації навчально-виховного процесу в закладах освіти.

При цьому кожен з трьох модулів курсу має свої конкретні мету і завдання. Так, метою модуля «Анатомія, фізіологія людини з основами медччних знань» є ознайомлення майбутніх вихователів ЗДО та вчителів 33СО з будовою тіла дитини, його органів і систем, вивчення взаємодії форми і функції в філогенетичному і онтогенетичному аспектах, а також взаємозумовленість структури і функції, залежність їх від зовнішніх умов існування організму як протягом усієї історії виду, так і у відносно короткий строк індивідуального розвитку. Відповідно основними завданнями цьього модуля є: ознайомлення з рівнями організації організму людини; встановлення взаємозв'язку будови органів 3 виконуваними функціями; формування поняття про взаємозалежність і єдність структури і функції органів дитини, та змін в процесі філогенезу й онтогенезу; посилення прикладного значення анатомо-фізіологічних знань, що дасть можливість майбутнім педагогам опанувати практичними навичками роботи з особистістю, що передбачає формування здатності ефективно вирішувати завдання щодо збереження i зміцнення як фізичного здоров'я дітей, так і власного.

Метою вивчення модуля «Психологічна антропологія» є формування у майбутніх вихователів ЗДО та вчителів початкових класів $33 \mathrm{CO}$ цілісного психологічного погляду на реальність людського буття у всіх 
його вимірах, розвиток інтересу до пізнання інших і самопізнання, а також здатності ефективно вирішувати завдання щодо збереження і зміцнення як психічного здоров'я дітей, так і власного. Відповідно основними завданнями изього модуля є: розвиток у студентів вільного розуміння та оперування понятійно-термінологічним апаратом дисципліни «Психологічна антропологія»; формування знання про основні теорії та підходи у психологічній науці та їх уявлення про сутність людини; формування знання про методи психологічного пізнання людини, а також уявлення про специфіку природничо-наукової та гуманітарної парадигми у пізнанні людини; формування знання про людину як суб'єкта свідомої діяльності, про психологічну структуру свідомості та діяльності людини, а також про професійну самосвідомість, самооцінку, самовизначення та інші структури у складі людської свідомості, які забезпечують професійне зростання студентів; формування знання про статево-вікові та індивідуально-типологічні (нейродинамічні) властивості людини як індивіда (іiі тілесного існування), зв'язок анатомії та психології, вищу нервову діяльність та функціональну організацію роботи мозку людини; формування знання про особливості основних психічних процесів (пізнавальних, емоційних та вольових), характеру та здібностей у структурі суб'єктності людини, а також про особливості їх розвитку у дітей дошкільного та молодшого шкільного віку; формування знання про основні характеристики людини як особистості, індивідуальності та універсальності (ії потреби, мотиви, смислові ставлення, ціннісні оріснтації); про місце і роль людини в системі її взаємозв'язків і відносин з іншими людьми; для здійснення рефлексивної психодіагностики, самопізнання рівня й особливостей власних професійно важливих якостей і властивостей, а також планування й реалізації різних видів діяльності для забезпечення безпеки діяльності власної та інших учасників освітнього процесу.

Метою вивчення модуля «Педагогічна антропологія» є систематизація та інтеграція у майбутніх вихователів ЗДО та вчителів початкових класів 3ЗСО теоретичних знань про людину, іiі освіту та розвиток; формування гуманістичного світогляду як основи особистісно-професійної й здоров' язберігальної діяльності. До основних завдань модуля відносяться: формування уявлення про основи сучасного людинознавства як цілісного знання про дитину; формування вміння використо- 
вувати знання 3 людинознавства для осмислення власного життєвого й педагогічного досвіду; створення умов для осмислення студентами власної педагогічної позиції на засадах гуманізму; розвиток вміння проєктувати програми особистісно-професійного розвитку з урахуванням індивідуальних та психологічних особливостей; формування професійно значущих якостей студентів у процесі самостійного опрацювання навчального матеріалу; стимулювати самовиховання, самовдосконалення та самоосвіту студентів.

Як бачимо, цей курс ефективно поєднує в собі психолого-педагогічну підготовку фахівця, при цьому надаючи також і знання з фізіологічних аспектів розвитку людини, що є невід’ємною складовою для цілісного розуміння її природи.

При викладанні модулів цього курсу, перш за все, необхідно налагодити ефективну взаємодію між усіма його викладачами. Так, кожному викладачеві, що викладає частину інтегрованого курсу, вкрай необхідно знати, які теми відображені у ньому в цілому, а не концентруватися лише на викладанні своїх тем. Корисною в цьому плані $є$ постійна організація та участь у різних спільних формах роботи круглих столах, міжкафедральних семінарах, конференціях, де можна детально розглянути і усвідомити актуальні проблеми, що пов’язані 3 одночасним викладанням тем цього курсу.

Важливим є взаємне обговорення усіма викладачами тем, модулів інтегрованого курсу з метою уникання негативних моментів у навчальному процесі (протиріч, повторів і т.д.). Часто буває так, що одні і ті ж самі теми повторюються у різних модулях курсу. Так, тема про вищу нервову діяльність людини (ВНД) за логікою має бути присутня і в модулі «Анатомія, фізіологія людини з основами медичних знань», i в модулі «Психологічна антропологія». I тут часто викладачі роблять помилку - просто дають знання з цієї теми. Ніби - то у цьому нічого поганого немає: те, що повторюється кілька разів краще запам'ятовується. Але ж набагато ефективніше може бути не просто механічно давати студентам один і той самий матеріал, а розмежувати, для чого саме він подається саме в кожному з названих модулів і акцентувати увагу на окремих його аспектах. Тобто у модулі «Анатомія, фізіологія людини з основами медичних знань» при вивченні теми про ВНД слід наголосити студентам, що вивчається саме будова центральної і пери- 
феричної нервової системи, іiі нейрофізіологічна основа, а у модулі «Психологічна антропологія» слід закцентувати увагу на їі функціонуванні і нейропсихологічних основах роботи нервової системи. Або ж, наприклад, якщо це тема, що стосується психічного розвитку людини в онтогенезі, то при вивченні модуля «Психологічна антропологія» слід акцентувати увагу на тому, що таке психічний розвиток взагалі, його основних вікових закономірностях, тоді як при вивченні аналогічної теми у модулі «Педагогічна антропологія» слід розглянути, як i де ці закономірності можна використати на практиці. Здавалося б, це зовсім прості і зрозумілі речі, але на практиці вони не завжди реалізовуються. Доцільно переглядати тематику модулів один одного, спільно обговорювати i, в разі необхідності, вносити корективи.

При вивченні тем модуля «Педагогічна антропологія» обов'язково слід давати студентам уявлення про практичний бік застосування набутих знань про фізіологію та психологію людини у їх майбутній професійній діяльності. I якщо з анатомією та фізіологією людини тут все більш-менш зрозуміло, тобто необхідно наголошувати на врахуванні фізіологічних основ дозрівання організму дитини у організації педагогічного процесу, то з особливостями поєднання психологічного та педагогічного знання все трохи складніше. Досить часто ми зіштовхуємося $з$ тим, що підходи до викладання психологічних та педагогічних дисциплін різні, і у викладачів виникає деякий «когнітивний дисонанс» при розумінні предмету, завдань і особливостей їх викладання саме у структурі інтегрованого курсу. Спробуємо розібратися детальніше у означеній проблемі.

Науковець Б.Бархаєв, опираючись на роботи П.Каптерева, вказує на те, що поєднання психологічних теорій з педагогічними може бути досягнуте різними шляхами [3, с. 16-19]. Так, перший шлях - це коли центр дослідницької уваги знаходиться в педагогіці, а психологічні дані грають роль неминучих передумов. В цьому випадку психологічні дані наводяться порівняно коротко і включають відносні роздуми про їх застосування у навчанні і вихованні. При цьому педагогічний процес (педагогічна взаємодія) розглядається з психологічної точки зору (С. Рубінштейн). У подібних випадках за основу структурування матеріалу приймаються основні поняття педагогіки як науки. Психологія ж виступає об'єктивним фактором (передусім, у вигляді індиві- 
дуально-психологічних особливостей учнів), який необхідно виявляти і враховувати у педагогічному процесі.

Інший варіант співвіднесення психологічного i педагогічного знання - це коли дається повна система психологічних пошуків і вказується можливість і спосіб застосування цих пошуків у навчанні та вихованні. В такому випадку центр тяжіння подібних робіт лежить в психології і педагогічні роздуми є простими висновками з психологічних даних. На перший план виступає зміст психологічних функцій, що реалізуються у процесі педагогічної взаємодії вчителя і учнів (Б.Бархаєв). При такому трактуванні об'єктом вивчення виступає не тільки сам учень, а й педагог, точніше система відносин «учень» - «вчитель».

Ще один напрямок у психолого-педагогічних дослідженнях - це всебічне вивчення дитини і обгрунтування педагогічної теорії експериментальним шляхом (педагогічний експеримент). Ця галузь науки розвивалась із вивчення дітей, і у неї була особлива практична ціль дослідити вплив шкільної роботи на дидактично значимі якості учнів.

Слід відзначити, що у вітчизняній та зарубіжній літературі достатньо широко представлені дослідження, центр дослідницької уваги яких знаходиться саме в педагогіці, а психологічні дані грають роль неминучих передумов психологічної педагогіки. На основі цього підходу й розробляються навчальні програми для навчання майбутніх фахівців у педагогічних вузах. I дійсно такі роботи представляють значний інтерес, однак досить часто при такому підході психологія «втрачається», на перший план висуваються педагогічні знання і тоді при ознайомленні студентів 3 даною наукою ми отримуємо такі досить невтішні статистичні результати, як значно «розмите», не структуроване усвідомлення необхідності застосування психологічних знань у майбутній професії, на що вказало проведене нами емпіричне дослідження.

На наш погляд, при викладанні тем модулів «Психологічна антропологія» та «Педагогічна антропологія» у структурі інтегрованого курсу «Людинознавство» головну увагу слід звертати на ті психологічні передумови, які досліджуються у якості значимих факторів педагогічного процесу. Тому у їх розробці та описі на перший план має виходити логіка психологічного аналізу освітньої реальності. У зв'язку з цим, слід пропагувати принцип, коли у центрі курсу стоїть саме психологія, а не педагогіка, дається повна система психологічних 
пошуків і вказується можливість і спосіб застосування цих пошуків у педагогічному процесі. У світовій практиці є роботи, що пропагують саме цей підхід (так, наприклад, книга «Прикладна педагогічна психологія» Гі Лефрансуа), що має справу з людською психікою і поведінкою у процесі навчання та виховання та займається застосуванням психологічного знання до проблем педагогічного процесу.

Зважаючи на це, щоб актуалізувати максимальне розуміння майбутніми педагогами, де і як можна використати ті чи інші психологічні знання у роботі з дітьми, на наш погляд, слід при вивченні модуля «Педагогічна антропологія» (особливо при вивченні, наприклад, таких його тем як «Чинники впливу на формування і розвиток особистості», «Методи виховання та їх класифікація») опиратися на теми з модуля «Психологічна антропологія», що пов'язані з психічним розвитком людини в онтогенезі та його основними закономірностями, пізнавальними процесами, особистісними характеристиками, такими як характер, темперамент, світогляд і т.д. Однак, (і що дуже важливо!) цей матеріал необхідно розглядати досить коротко, актуалізуючи його у пам'яті студентів, а основну увагу звертати на конкретних практичних аспектах його використання у педагогічній роботі.

\section{5. Висновки}

Таким чином, на основі аналізу теоретико-методологічної бази дослідження нами було проведено власне емпіричне вивчення особливостей усвідомлення майбутніми педагогами необхідності набуття психологічних компетенцій, а також охарактеризовано важливі практичні аспекти інтеграції психологічних і педагогічних знань для підготовки майбутніх педагогів у процесі викладання інтегрованих дисциплін психолого-педагогічного циклу, зокрема, такого інтегрованого курсу як «Людинознавство».

Проведене дослідження дозволило констатувати, що значна частина опитаних студентів в цілому усвідомлюють необхідність застосування психологічних знань у майбутній професії, однак, зазначимо, що таке усвідомлення значно «розмите», не структуроване, оскільки конкретизувати найбільш поширену відповідь «необхідно використовувати у роботі $з$ дітьми» більшість студентів так і не змогли. Також студенти у переважній більшості повністю не усвідомлюють, з якою метою 
психологічні та педагогічні дисципліни об'єднані у загальний інтегрований курс. Ніхто із студентів не дав розгорнутої відповіді, де б могла прослідковуватися їх думка щодо інтеграції кількох дисциплін в одну. Такі показники можуть свідчити про недостатність проведення роботи з впровадження інтегрованого та міждисциплінарного підходів і потребують посиленої уваги та злагодженої спільної роботи фахівців, що викладають такий курс. Крім того, більше відповідей ми отримали таких, що психологічні знання практично використовуються студентами для покращення їх власного життя та особистісного саморозвитку. У зв'язку з цим, фахівцям, що займаються психолого-педагогічною підготовкою майбутніх вихователів, слід активувати роботу у напрямку вирішення цих проблем.

Закріплення у свідомості майбутніх педагогів правильного поєднання психологічних і педагогічних знань у процесі їх підготовки визначається чітким розумінням викладачами дисциплін психологічного і педагогічного циклу необхідності взаємодії між собою та орієнтації на практичну сторону застосування їх предмету. Особливо це стосується викладачів інтегрованого курсу «Людинознавство», оскільки у самому предметі даного курсу закладені могутні можливості для цього. У цьому аспекті важливим видається погляд на таке структурування та викладання даного курсу, коли у центрі вивчення перебувають психологічні поняття та категорії, тобто повна система психологічних пошуків і вказується можливість та спосіб застосування цих пошуків у педагогічному процесі.

Перспективою подальших досліджень є конкретизація тематики інтегрованого курсу «Людинознавство» у процесі підготовки майбутніх педагогів та розробка більш ефективних методів і прийомів формування у студентів психологічного погляду на педагогічні проблеми під час викладання даного курсу.

\section{Список літератури:}

1. Андронова Н.В. Умение разрабатывать психолого-педагогические рекомендации как компонент психологической компетентности учителя : автореф. дис. канд. психол. наук. Казань, 2000.

2. Бакаленко О.А. Психологічна компетентність як ключова компетентність сучасного фахівця. Вісник Харківського університету. Сер. Теорія культури і філософія науки. 2018. № 58. С. 132-138. 
3. Бархаев Б.П. Педагогическая психология. Санкт-Петербург : Питер, 2007.

4. Ги Лефрансуа. Прикладная педагогическая психология. СанктПетербург : прайм-ЕВРО-ЗНАК (Проект «Главный учебник»), 2005.

5. Вахромов Е.Е. Вершины жизни и пути их достижения. Прикладная nсихология и психоанализ. 2001. № 4. С. 18-23.

6. Державна національна програма «Освіта» («Україна XXI століття»). Київ : Райдуга, 1994.

7. Срмаков T.I. Індивідуальне розуміння концепту «Я» як ключова компетентність особистості в умовах сучасного інформаційного суспільства. Наукові студї із соиіальної та політичної психології : зб. статей. 2002. № 6(9). C. 200-207.

8. Кочерга О.В. Розвиток психологічної компетентності вчителя початкової школи. Рідна школа. 2013. № 11. С. 52-56.

9. Кузьмина Н.В. Профессионализм педагогической деятельности. Санкт-Петербург : СПбГу, 1993.

10.Красильник Ю.С. Психолого-педагогічна компетентність як складова педагогічної майстерності науково-педагогічного працівника. Вісник Наиіональної академії Державної прикордонної служби України. 2010. № 1. URL: http://nbuv.gov.ua/UJRN/Vnadps_2010_1_12

11. Маркова А.К. Психология професссионализма. Москва, 1996.

12.Мельник I.C. Особливості усвідомлення майбутніми вихователями необхідності набуття психологічних компетенцій. Особистісно-професійна підготовка вчителя до здійснення навчально-творчої діяльності молодшого школяра: Збірник праџь науково-практичної конференцї (Київський університет імені Бориса Грінченка, Педагогічний інститут, Інститут післядипломної педагогічної освіти, м. Київ, 17-18 травня 2012 р.). Київ, 2012.

13.Мельник І.С. Практичні аспекти інтеграції психологічних і педагогічних знань у процесі підготовки майбутніх педагогів. Збірник наукових праиь Інституту психологї імені Г.С. Костюка. Психологія особистості. Психологічна допомога особистості. 2012. № 11(6). С. 386-392.

14. Мельник I. Проблема вивчення психологічного складника здоров'язбережувальної компетентності майбутніх педагогів: системний підхід. Освітологічний дискурс. 2020. № 3. С. 221-239.

15.Піроженко Т.О. Хто реформує освіту - той реформує суспільство. С.Д. Максименко \& С.О. Ладивір (Ред.). Актуальні проблеми психології. Психологія розвитку дошкільника : зб. наук. статей. 2008. № 4(5). С. 96-102.

16.Садова I. Проблеми удосконалення професійної підготовки майбутнього вчителя у педагогічній теорії. Молодь і ринок. 2012. № 1(84). С. 80-84.

17.Хоружа Л.Л. Теоретичні засади формування етичної компетентності майбутніх учителів початкових класів : дис. докт. пед. наук. Київ, 2004.

18.Цільмак О.М. Складові структури компетентностей. Наука $і$ освіта: науково-практичний журнал Південного наукового Центру АПН Украӥни. 2009. № 1-2. С. 128-134.

19. Чайка В.М. Проблеми змісту підготовки майбутніх вихователів дошкільних навчальних закладів до інноваційної педагогічної діяльності. Г. Терещук (Ред.). 
Наукові записки Тернопільського національного педагогічного університету ім. Володимира Гнатюка. Сер. Педагогіка. 2012. № 2. С. 33-39.

20. Щербакова Т.Н. Психологическая компетентность учителя: акмеологический анализ : автореф. дис. д-ра психол. наук. Ростов-на-Дону, 2006.

21. Liu W.C. The Teaching Profession and Teacher Education. In: Tan O., Low E., Hung D. (eds) Lee Kuan Yew's Educational Legacy. Springer, Singapore. 2017.

\section{References:}

1. Andronova, N.V. (2000). Umenie razrabatyvat' psihologo-pedagogicheskie rekomendacii kak komponent psihologicheskoj kompetentnosti uchitelja [The ability to develop psychological and pedagogical recommendations as a component of the teacher's psychological competence]: avtoref. dis. ... kand. psihol. nauk: 19.00.07. Kazan'. (in Russian)

2. Bakalenko, O.A. (2018). Psykhologhichna kompetentnistj jak kljuchova kompetentnistj suchasnogho fakhivcja [Psychological competence as a key competence of a modern specialist]. Visnyk Kharkivsjkogho universytetu. Ser. Teorija kuljtury i filosofija nauky, vyp. 58, 132-138. (in Ukrainian)

3. Barkhaev, B.P. (2007). Pedagogicheskaya psikhologiya [Pedagogical psychology]. SPB: Piter. (in Russian)

4. Gi Lefransua (2005). Prikladnaya pedagogicheskaya psikhologiya [Applied pedagogical psychology]. SPb: praym-EVRO-ZNAK (Proekt «Glavnyy uchebnik»). (in Russian)

5. Vahromov, E.E. (2001). Vershiny zhizni i puti ih dostizhenija [Tops of life and ways to achieve them]. Prikladnaja psihologija i psihoanaliz, 4, 18-23. (in Russian)

6. Derzhavna nacionaljna proghrama «Osvita» («Ukrajina XXI stolittja»). (1994) [State National Program "Education" ("Ukraine of the XXI Century")]. Kyiv: Rajdugha. (in Ukrainian)

7. Jermakov, T.I. (2002). Indyvidualjne rozuminnja konceptu «Ja» jak kljuchova kompetentnistj osobystosti $\mathrm{v}$ umovakh suchasnogho informacijnogho suspiljstva [Individual understanding of the concept of «I» as a key competence of the individual in today's information society]. Naukovi studiji iz socialjnoji ta politychnoji psykhologhiji: zb. statej. Kyiv: Milenium, vyp. 6(9), 200-207. (in Ukrainian)

8. Kochergha, O.V. (2013). Rozvytok psykhologhichnoji kompetentnosti vchytelja pochatkovoji shkoly [Development of psychological competence of primary school teachers]. Ridna shkola, 11, 52-56. (in Ukrainian)

9. Kuz'mina, N.V. (1993). Professionalizm pedagogicheskoy deyatel'nosti [Professionalism of teaching activities]. SPb: SPbGu. (in Russian)

10. Krasyljnyk, Ju.S. (2010). Psykhologho-pedaghoghichna kompetentnistj jak skladova pedaghoghichnoji majsternosti naukovo-pedaghoghichnogho pracivnyka [Psychological and pedagogical competence as a component of pedagogical skills of a scientific and pedagogical worker]. Visnyk Nacionaljnoji akademiji Derzhavnoji prykordonnoji sluzhby Ukrajiny, 1. (in Ukrainian)

11. Markova, A.K. (1996). Psikhologiya professionalizma [Psychology of professionalism]. Moskva. (in Russian) 
12. Meljnyk, I.S. (2012). Osoblyvosti usvidomlennja majbutnimy vykhovateljamy neobkhidnosti nabuttja psykhologhichnykh kompetencij [Features of awareness of future educators of the need to acquire psychological competencies]. Osobystisnoprofesijna pidghotovka vchytelja do zdijsnennja navchaljno-tvorchoji dijaljnosti molodshogho shkoljara: Zbirnyk pracj naukovo-praktychnoji konferenciji (Kyjivsjkyj universytet imeni Borysa Ghrinchenka, Pedaghoghichnyj instytut, Instytut pisljadyplomnoji pedaghoghichnoji osvity, m. Kyjiv, 17-18 travnja 2012 r.). Kyiv. (in Ukrainian)

13. Meljnyk, I.S. (2012). Praktychni aspekty integhraciji psykhologhichnykh i pedaghoghichnykh znanj u procesi pidghotovky majbutnikh pedaghoghiv [Practical aspects of integration of psychological and pedagogical knowledge in the process of training future teachers]. Zbirnyk naukovykh pracj Instytutu psykhologhiji imeni Gh.S. Kostjuka. Psykhologhija osobystosti. Psykhologhichna dopomogha osobystosti, 11(6), 386-392. (in Ukrainian)

14. Meljnyk, I. (2020). Problema vyvchennja psykhologhichnogho skladnyka zdorov'jazberezhuvaljnoji kompetentnosti majbutnikh pedaghoghiv: systemnyj pidkhid [The problem of studying the psychological component of health competence of future teachers: a systematic approach]. Osvitologhichnyj dyskurs, 3, 221-239. (in Ukrainian)

15. Pirozhenko, T.O. (2008). Khto reformuje osvitu - toj reformuje suspiljstvo [He who reforms education reforms society]. S.D. Maksymenko \& S.O. Ladyvir (Red.). Aktualjni problemy psykhologhiji. Psykhologhija rozvytku doshkiljnyka: zb. nauk. statei, 4(5), 96-102. (in Ukrainian)

16. Sadova, I. (2012). Problemy udoskonalennja profesijnoji pidghotovky majbutnjogho vchytelja u pedaghoghichnij teoriji [Problems of improving the professional training of future teachers in pedagogical theory]. Molodj i rynok, 1(84), 80-84. (in Ukrainian)

17. Khoruzha, L.L. (2004). Teoretychni zasady formuvannja etychnoji kompetentnosti majbutnikh uchyteliv pochatkovykh klasiv [Theoretical bases of formation of ethical competence of future teachers of initial classes]: dys. dokt. ped. nauk. Kyiv. (in Ukrainian)

18. Ciljmak, O. M. (2009). Skladovi struktury kompetentnostej [Components of competency structures]. Nauka i osvita: naukovo-praktychnyj zhurnal Pivdennogho naukovogho Centru APN Ukrajiny, 1-2, 128-134. (in Ukrainian)

19. Chajka, V.M. (2012). Problemy zmistu pidghotovky majbutnikh vykhovateliv doshkiljnykh navchaljnykh zakladiv do innovacijnoji pedaghoghichnoji dijaljnosti [Problems of the content of preparation of future educators of preschool educational institutions for innovative pedagogical activity]. Gh.Tereshhuk (Red.), Naukovi zapysky Ternopiljsjkogho nacionaljnogho pedaghoghichnogho universytetu im. Volodymyra Ghnatjuka. Ser. Pedaghoghika, 2, 33-39. (in Ukrainian)

20. Shherbakova, T. N. (2006). Psihologicheskaja kompetentnost' uchitelja: akmeologicheskij analiz [Teacher Psychological Competence: Acmeological Analysis]: avtoref. dis. ... d-ra psihol. nauk: 19.00.13. Rostov-na-Donu, 41. (in Russian)

21.Liu W.C. (2017). The Teaching Profession and Teacher Education. In: Tan O., Low E., Hung D. (eds). Lee Kuan Yew's Educational Legacy. Springer, Singapore. (in English) 